\title{
The Analysis of the Doctors' Perspective on the Traditional, Complementary and Alternative Medicine
}

\author{
Gordana D. Marković Petrović1 ${ }^{1}$ Gordana B. Belamarić ${ }^{2}$ \\ ${ }^{1}$ Department for Specialist and Consultative activities, Primary Healthcare Center Zemun, \\ Belgrade, Serbia \\ ${ }^{2}$ City Institute for Public health Belgrade, Belgrade, Serbia
}

\section{SUMMARY}

Introduction: The application of traditional, complementary and alternative medicine (TCAM) has been increasing and gaining popularity over the past two decades. This is mostly the result of the patients changing their lifestyle and searching for new forms of non-invasive, natural therapy. Even though the World Health Organization has recognized the importance of TCAM, the majority of doctors are still not ready to accept TCAM as a legitimate form of medical treatment. Thus many patients use TCAM without doctors' consent, which can result in delaying or avoiding the use of adequate treatments in conventional medicine. Also, there is the possibility of interaction between conventional medications and the preparations used in TCAM. All of this can potentially result in a major public health problem.

Aim: The aim of this research is to determine the doctor's perspective about TCAM, and to form a valid instrument that would be used in this and all future trials.

Methods: A questionnaire was used as the data collection tool. The analyses used in the statistical processing of the obtained results are: the multiple correspondence analysis, discriminant analysis, Mann-Whitney testing and the ROC curve procedure. Results: 110 doctors were examined, 24 of whom have been trained in one of the TCAM methods. By multiple correspondence analysis, regarding the responses, three dimensions of TCAM acceptance have been identified. The total explained variance is $98.36 \%$, and the average value of the Cronbach's alpha coefficient for all three dimensions is 0.929 .

Conclusions: Educating physicians to use traditional, complementary and alternative medicine plays a decisive role in their acceptance of these methods. It is also of great importance, since there is an increasing number of patients who use TCAM methods without medical supervision.

Keywords: traditional, complementary, alternative medicine, doctors, attitudes 


\section{INTRODUCTION}

Traditional medicine represents "health practices, approaches, knowledge and beliefs relating to preparations made of plant, mineral or animal origin, spiritual therapies, as well as manual techniques and exercises that are applied either individually or combined, for the purpose of treating, diagnosing and preventing disease, that is, for the sake of preserving the welfare" [1].

The term traditional medicine has been officially introduced by the World Health Organization (WHO), and besides the aforementioned term, the professionals also use other terms, such as complementary and alternative medicine (CAM-complementary and alternative medicine), integrative medicine, integrated medicine and vibratory medicine.

According to the definition given by the American National Center for Complementary and Alternative Medicine, CAM represents "a group of different medical systems, practices and products that are used for health care along with conventional medicine, however, they are not considered to be a part of conventional medicine."

There have been numerous attempts to resolve the dilemma over which name is the most acceptable, however the consensus has not been reached. As a compromise, the term most commonly used is "traditional, complementary and alternative medicine (TCAM)" and it will also be used in this paper.

Expanding the application of the TCAM method has raised many questions among healthcare professionals and posed new challenges concerning the safety and efficiency of the application of these methods, as well as the need to control the quality of medicines and procedures that are applied to the TCAM framework [2 - 10].

In 2005, the Ministry of Health of the Republic of Serbia adopted the Rulebook on detailed terms, manners and procedures of performing traditional medicine in a health institution, mainly in private practice [11]. According to data obtained from the Ministry, 220 TCAM licenses have been issued so far: 29 licenses were issued to health care institutions and 30 employees in these health institutions. 161 licenses have been issued to private practices and their employees. Most of the licenses were issued for performing acupuncture (133), homeopathy (69), quantum medicine
(52), macrobiotics (4), reiki and shiatsu massage (6), apitherapy (2), yoga practice (3), chiropractic (2) and Chinese traditional medicine (2).

Despite the importance of TCAM was recognized by the WHO, most doctors are not ready still to accept these methods as a legitimate form of medical treatment. The difference in opinion on the use of TCAM among doctors of conventional medicine and patients carries the risk that patients use this method without the consent of their doctors. The results of the study conducted by Eisenberg et. al showed that as many as $72 \%$ of patients use TCAM without the knowledge of their doctor [12]. This is potentially the major public health issue and carries a great deal of risk to the patients, as it can lead to postponement or avoidance of the use of conventional treatments. Also, the simultaneous administration of medications used in some TCAM treatments and those recommended by conventional medicine could lead to fatal interactions [13 - 14]. The objective of this research is to determine the doctors' perspective about TCAM and to create a valid instrument that would be used in this and all future trials.

\section{AIM}

The aim of this research is to determine the doctors' perspective about TCAM and to create a valid instrument that would be used in this and all future trials.

\section{METHODS}

This was a cross-section study, with a survey done on October 6th, 2012, at the International Congress of Private Medical Practice of Serbia, Belgrade, Serbia. As there were several lectures on TCAM on that day, many doctors who were further educated in this area were expected to attend the congress. The sample consisted of congress participants who were willing to cooperate. The TCAM questionnaires, (Appendix 1), were distributed in the lobby outside the hall during the period between 2 and $3 \mathrm{pm}$, where, starting at $3 \mathrm{pm}$, several different lectures on TCAM were about to be held. The participants were asked to return the questionnaires by the completion of the final lecture (around 6 p.m.). 
To collect data for the purposes of this research, a three-part TCAM questionnaire was created:

- The first part was related to the data on gender, year of birth, occupation, years at work, specialization, education in the field of traditional medicine and the type of institution in which they work. Data on the gender and type of the institution is obtained by multiple choice answers, while the other data was provided by respondents by correspondence. All data, except for the specialization, which is entered in the table, is encoded in the following way: gender, occupation (doctor $=1$; nurse $=2$; dentist $=3$; pharmacist $=4$; other $=5$ ), years of work experience $(0-10=1 ; 11-20=2 ; 21-30$ $=3 ;>30=4)$, traditional medicine education (yes/no) and type of institution in which you work (private/state-owned).

- The second part consists of 13 questions, selected from two questionnaires that were used in two independent research studies [15-16] They surveyed the doctors' perspective on TCAM methods. Respondents were asked to answer questions by choosing one of the three offered responses, encoded as follows: yes $=1$, no $=2$ and $I$ do not know $=3$.

- The third part consists of three questions. The first two questions relate to the physician's willingness to recommend TCAM methods to their patients and their willingness to use them for themselves, while the third question surveys the interest in introducing education on TCAM methods should into the curriculum of all levels of the medical education programs. Respondents answered by choosing one of the offered responses encoded as follows: yes $=1$; no $=2$ and $\mathrm{I}$ do not know $=3$.

\section{Statistical methods}

The frequency and percentage were used to describe the set of nominal data. The numerical variables were shown as median with an interquartile range.

Multiple correspondence analysis was used as an appropriate optimal scaling method for the assessment of structural validity and definition of the basic dimensions of the measuring instrument. Reliability of each dimension is measured by Cronbach's alpha coefficient. Answers with the average variation less than or equal to $10 \%$ in terms of the given dimensions are considered constructively non-volatile and are eliminated from further processing.

The difference between education categories (gender, years of work experience, type of institution, scores from the second part of the scale of the TCAM Questionnaire) was estimated by discriminant analysis. The Mann-Whitney test was used to estimate differences in the total TCAM score between groups. Assessment of the validity of the total discriminant score was obtained by analyzing the second dimension of the TCAM questionnaire by the respondents who were educated in any of the TCAM methods. It was conducted by using the Receiver operating characteristic procedure.

\section{RESULTS}

A total of 135 questionnaires were distributed, and 117 were received back. $81 \%$ of the questionnaires were filled in completely, and those were used in further research. Respondents

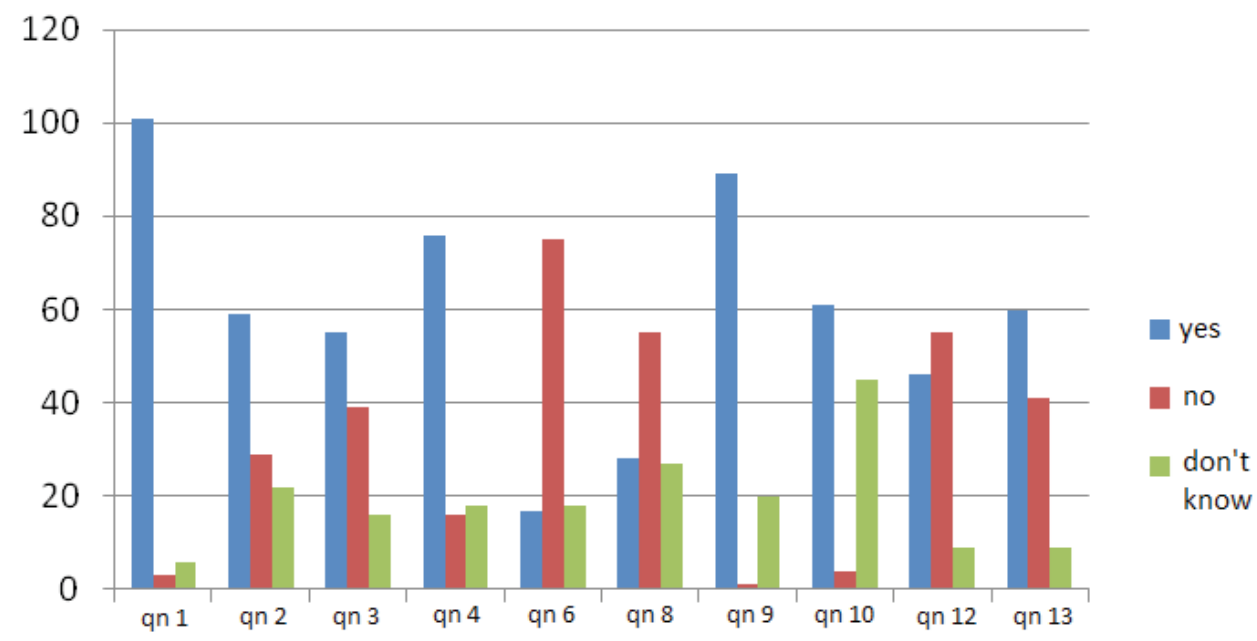

Figure 1. The frequency according to the items and modalities of the responses 
were represented by 110 doctors, 41 men and 69 women. 24 respondents have received education in any of the TCAM methods.

70 respondents work in a stateowned health institution. 39 respondents had 0-10 years of work experience. 6 respondents had more than 30 years of work experience. The largest number of respondents had between 11 and 20 years of work experience; 17 respondents had between 21 and 30 years of work experience. The frequency displayed according to the modalities of the responses and dimensions of the second part of the TCAM questionnaire is given in Figure 1.

Three questions (qn5, qn7 and qn11) from the second part of the TCAM questionnaire were excluded from the analysis because they did not provide enough variance. In all three obtained dimensions, the average score of the explained variance was less than $10 \%$. Consequently, from this part of the TCAM questionnaire, 10 questions were entered into the subject of further analysis (hereinafter: TCAM10 questionnaire).

By analyzing the correspondence according to the responses to these 10 questions, three dimensions of acceptance of the TCAM method in treatment were identified. The first dimension of explained variance was around $55 \%$, the second $24 \%$, and the explained variance of the third dimension was around 20 $\%$. The total explained variance was $98.36 \%$ (Table 1).

The first dimension was named "The dimension of resistance of the respondents to the basic postulates of the TCAM method". It consists of five questions (qn2, qn4, qn9, qn10 and qn13) that do not show significant variation from the other two dimensions. The Cronbach's alpha coefficient for the first dimension issue was 0.972 (Table 1).

The second dimension was defined as the dimension of accepting TCAM as an auxiliary method in conventional treatment. It consists of 3 questions (qn1, qn3, qn12). The Cronbach's alpha coefficient for the second dimension question set was 0.889 (Table 1). The third dimension was named the TCAM method of non-acceptance and its Cronbach's alpha coefficient was 0.859 (Table 1).

From the centroid coordinates of the in the first dimension shown that the centroid of the NO and DON'T KNOW response categories have very high values in relation to the YES response category in questions 2, 4, 9 and 10. It also shows that the YES response category has very high values in the first dimension for question 13. In calculation score per dimension and the total score, the aforementioned response categories in the questions forming the first dimension were given one point, while the other categories were given zero points. The maximum score for the first dimension is 5 .

From the centroid coordinates of the in the second dimension shown that the centroid of the DON'T KNOW response category has very low values compared to the other cat-
Table 1. Multiple correspondence analysis parameters of the TCAM10 questionnaire

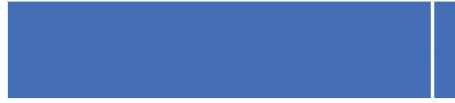

Number of categories

\section{qn 1}

qn 2

qn 3

qn 4

qn 6

qn 8

qn 9

qn 10

qn 12

qn 13

Correspondence analysis

parameters

Eigenvalue

Percent of variance

Cronbach's alfa

(⿸丆口

Total

\begin{tabular}{|c|c|c|c|}
\hline \multicolumn{3}{|c|}{ Dimension } & \multirow{2}{*}{ Mean } \\
\hline 0.077 & 0.480 & 0.056 & 0.204 \\
\hline 0.633 & 0.078 & 0.081 & 0.264 \\
\hline 0.047 & 0.421 & 0.088 & 0.419 \\
\hline 0.469 & 0.271 & 0.031 & 0.257 \\
\hline 0.280 & 0.204 & 0.638 & 0.474 \\
\hline 0.368 & 0.349 & 0.593 & 0.437 \\
\hline 0.456 & 0.011 & 0.182 & 0.216 \\
\hline 0.716 & 0.077 & 0.126 & 0.306 \\
\hline 0.542 & 0.524 & 0.082 & 0.383 \\
\hline 0.621 & 0.247 & 0.090 & 0.319 \\
\hline
\end{tabular}

29.512

98.36

55.077

0.972

7.087
23.624
0.889

5.901

9.837

19.671

\begin{tabular}{l|l}
0.889 & 0.859
\end{tabular}

0.929 
egories in questions 1,3 , and 12 . This response category was also given one point, while the rest of the response categories of the second dimension were given zero points. The maximum score for the second dimension is 3 .

In a similar way, it was noticed that the centroid of the YES response categories in questions 6 and 8 has very high values in the third dimension in relation to other categories. The response category YES was also given one point. The maximum score for the second dimension is 2 .

Therefore, a negative scale of measuring the acceptance of TCAM was obtained for the TCAM10 questionnaire, ranging from 0 to 10 , with 0 indicating the highest and 10 indicating the lowest level of acceptance of TCAM in treatment.

The average acceptance score in the overall population was 2 , with interquartile range from 0 to 5 . In the group of subjects who were educated in any of the TCAM methods, the average score and the interquartile range were 0 . The average total TCAM10 score of the respondents without education was 3 , with interquartile range from 1 to 5 . The average of the total TCAM10 score was significantly higher in the female population (MannWhitney $\mathrm{U}=326 ; \mathrm{z}=-5.218 ; \mathrm{p}<0.0001$ ) and it amounted to 1 , with an interquartile range of 0 to 4 , while the overall score in men was 3 , with an interquartile range from 0 to 6 .

The discriminant analysis has shown that there is a very significant association of gender variables, types of institution, total TCAM score, and the first and the third dimension of TCAM10 scores within respondents who were educated in any of the TCAM methods, compared to those without education in TCAM methods. A significant discriminant equation of was obtained (Wilks' Lambda $=0.660$; Hi-square $=42.425 ; \mathrm{df}=1$; $\mathrm{p}<0.0001)$. The canonical discriminant cot ficient was 0.575 .

Respondents who passed the educ tion had lower values for the first dimensic score $(\mathrm{F}=28.117 ; \mathrm{df}=2 ; \mathrm{p}<0.0001)$ and $\mathrm{t}]$ third dimension score $(\mathrm{F}=6.597 ; \mathrm{df}=2 \mathrm{p}$ 0.012 ), in addition to lower values for the $t$ tal score. Among this group of responder there were more women $(\mathrm{F}=11.995 ; \mathrm{df}=$ $\mathrm{p}=0.001)$, and private sector employees ( $\mathrm{F}$ 4.292; $\mathrm{df}=2 ; \mathrm{p}<0.041$ ).

In a group of 43 respondents wl gave an affirmative response to the questic
"Would you recommend some of the methods of traditional, complementary and alternative medicine to their patients?" a significantly lower total score was obtained (Mann-Whitney U $=372 ; \mathrm{z}=-6.684 ;<0.0001)$ with median of 0 and interquartile range from 0 to 1 , compared to 67 patients who gave a negative response (Med $=4$ with an interquartile range from 2 to 6).

Within a group of 52 respondents who gave an affirmative response to the question "Would you apply any of the TCAM methods yourself?" a significantly lower total score was obtained (Mann-Whitney $\mathrm{U}=334$; $\mathrm{z}=$ 7.178; $p<0.0001)$ with median of 0 and interquartile range from 0 to 1 , compared to $58 \mathrm{pa}-$ tients who gave a negative response ( $\mathrm{Med}=4$ with an interquartile range from 3 to 6 ).

Within a group of 82 respondents who gave an affirmative response to the question "Do you think that education on TCAM methods should be introduced into the curriculum of medical schools at all levels?" a significantly lower total score was obtained (MannWhitney $\mathrm{U}=444 ; \mathrm{z}=-4.933 ; \mathrm{p}<0.0001$ ) with a median of 1 and an interquartile range from 0 to 3 , compared to 28 patients who gave a negative response $(\mathrm{Med}=6$ with an interquartile range from 3.25 to 7 ). The ROC procedure shows that there is a significant area below the curve of the discriminant score, which identifies subjects with education in any of the traditional medicine methods vs subjects without education in any of the traditional medicine methods (AUROC $=0.842 ; \mathrm{p}<0.0001$, with a lower limit of $95 \%$ confidence interval of 0.742 and upper limit of 0.942 ). For the "CUT POINT" value of discriminant score was 1.5 with sensitivity $=82.6 \%$ and specificity $=87.5$ $\%$ (Figure 2).

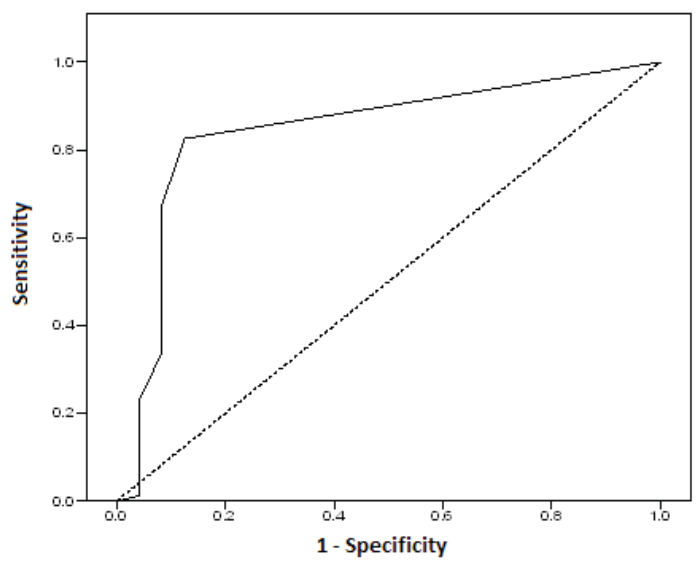

Figure 2. ROC curve of the discriminant score classifying respondents who had education in any of the traditional, complementary and alternative medicine methods vs respondents who had not education 


\section{DISCUSSION}

Questions number 5, 7, and 11 were excluded from further analysis, due to structural invalidity. In other words, these issues were rejected, since they did not provide consistent explanations. Also, in this study it was shown that attitudes of doctors on TCAM are not linear, similar to the attitude of medical experts on conventional medical diagnostic and curative procedures [17-19].

The analysis of the responses that belong to the first part showed that about 92 $\%$ of doctors think that "illness and health are a reflection of the balance between positive forces, which makes a person feel happy in life, and destructive negative forces", which suggests that, among the respondents, even doctors who have not completed education in any of the TCAM methods have a holistic way of thinking.

In addition, as many as $81 \%$ of surveyed physicians said that "Traditional, complementary and alternative medicine include ideas and methods that could be beneficial to conventional medicine," which indicated their willingness to implement TCAM knowledge and skills in their everyday work. In addition, almost $70 \%$ of them did not consider TCAM as a threat to human health.

On the other hand, only $39 \%$ of the surveyed doctors stated that they were ready to recommend any of the TCAM methods to their patients.

The obtained results coincided with similar research conducted at the Mayo Clinic in Rochester [20]. The results showed that even though the majority of doctors agreed that TCAM methods could give positive results in treating various symptoms and illnesses, most of them did not advise their patients to use them. Milden et al [21] surveyed a random sample of doctors in California, and despite the overall positive attitude of doctors regarding TCAM methods, $61 \%$ of them considered that they were not sufficiently familiar with their efficacy and safety, while $81 \%$ expressed a desire for additional education in the field of TCAM. The aforementioned data also coincided with the results of this study in which as many as $83 \%$ of the surveyed doctors responded that they believed that education on TCAM methods should be introduced into the curriculum at all levels of the medical education curriculum.
Around 55\% of the surveyed doctors in this study believed that TCAM should be used in the treatment of mild illnesses rather than in the treatment of serious ones. Besides, the analysis of the answers regarding the acceptance of TCAM as an auxiliary method in conventional treatment showed that $55 \%$ of the examined doctors think that most TCAM methods stimulate the natural therapeutic powers of the body, and only less than $4 \%$ did not think so (Figure 1). Accordingly, $47 \%$ of the answers to the question "Would you use some of the TCAM methods for yourself" were affirmative. The results of the study conducted by Jump et al [22], showed that most doctors did not consider TCAM as a part of legitimate medical practice, but about $2 / 3$ of the same doctors had recommended at least one of the TCAM methods to their patients.

The analysis of the responses received in this study, as well as in other studies mentioned above, provides data on numerous contradictions. Based on this data the impression is that doctors feel apprehensive to accept openly the practice of TCAM methods. Because of this, it is necessary to carry out additional medical research, which would provide new evidence and assist the healthcare professionals in understanding and accepting TCAM.

The results of the study also show that a group of subjects who received education in any of the TCAM methods displayed a higher degree of TCAM acceptance. Their scores for the first and third dimension were lower, which was expected given the fact that they were familiar with the safety of the application, indications, contraindications and side effects of these methods. Moreover, among these respondents, there were notably more women and employees in the private sector.

Barnes et al [23] published the results of the National Health Survey conducted in the US, which showed that most of the users of the TCAM methods were, in fact, highly educated, career-oriented women who were in their reproductive prime.

The results of an Israeli study showed that patients expected their family doctors to be educated in the application of the TCAM methods [24]. They were also expected to follow trends related to this area and recommend appropriate TCAM methods in the health in- 
stitutions. TCAM methods were expected to be integrated into primary health care.

The results show that, concerning the acceptance dimension of the TCAM method as an auxiliary method in conventional treatment, no statistical differences were found between doctors who completed education from one of the TCAM methods and those who did not.

\section{CONCLUSION}

Educating physicians in traditional, complementary and alternative medicine plays a decisive role in their acceptance of these methods. It is also of great importance since there is an increasing number of patients who use TCAM methods without medical supervision.

\section{CONFLICT OF INTEREST}

The authors deny any potential conflicts of interest.

\section{FINANCIAL DISCLOSURE STATEMENT}

The authors did not receive any funds for this study.

\section{REFERENCES}

1. World Health Organization. Traditional Medicine Strategy 2002-2005 (WHO/EDM/TRM/2002.1). Geneva, Switzerland: World Health Organization; 2002.

2. Black LI, Barnes PM, Clarke TC, Stussman BJ, Nahin RL. Use of yoga, meditation, and chiropractors among U.S. children aged 4-17 years. NCHS Data Brief. 2018; (324):1-8.

3. Clarke TC, Barnes PM, Black LI, Stussman BJ, Nahin RL. Use of yoga, meditation, and chiropractors among U.S. adults aged 18 and older. NCHS Data Brief. 2018; (325):1-8.

4. Lindly O, Thorburn S., Zuckerman K. Use and nondisclosure of complementary health approaches among US children with developmental disabilities. Journal of Developmental \& Behavioral Pediatrics. 2018; 39(3):217-227.

5. Mbizo J, Okafor A, Sutton MA, et al. Complementary and alternative medicine use among persons with multiple chronic conditions: results from the 2012 National Health Interview Survey. BMC Complementary and Alternative Medicine. 2018; 18(1):281.
6. Groenewald CB, Beals-Erickson SE, Ralston-Wilson J, et al. Complementary and alternative medicine use by children with pain in the United States. Academic Pediatrics. 2017; 17(7):785-793.

7. Henson JB, Brown CL, Chow SC, et al. Complementary and alternative medicine use in United States adults with liver disease. Journal of Clinical Gastroenterology. 2017; 51(6):564-570.

8. Sirois FM, Jiang L, Upchurch DM. Use and disclosure of complementary health approaches in US adults with cardiovascular diseases. American Journal of Cardiology. 2018; 122(1):170-174.

9. Upchurch DM, Gill M, Jiang L, et al. Use of mindbody therapies among young adults aged 18-24 years: findings from the 2012 National Health Interview Survey. Journal of Adolescent Health. 2018; 63(2):227-232.

10. Pure E, Terhorst L, Baker N. Movement and manual therapy for adults with arthritis: $2012 \mathrm{Na}$ tional Health Interview Survey. Complementary Therapies in Medicine. 2018; 37:96-102.

11. Pravilnik o bližim uslovima, načinu i postupku obavljanja metoda i postupaka tradicionalne medicine, "Sl. glasnik RS", br. 16/2018.

12. Eisenberg DM, Davis RB, Ettner SL, Appel S, Wilkey S, Van Rompay M, et al. Trends in alternative medicine use in the United States, 19901997: results of a follow-up national survey. JAMA. 1998;280:1569-1575.

13. Fugh-Berman A. Herb-drug interactions. Lancet. $2000 ; 355: 134-138$.

14. Fugh-Berman A, Ernnst E. Herb-drug interaction: review and assessment of report reliability. British Journal of Clinical Pharmacology. 2002; 52:587-595.

15. Halterman-Cox M, Sierpina VS, Sadoski M, Sanders C. CAM attitudes in first- and second-year medical students: a pre-and post-test course survey. Integr Med. 2009;7(6):34-42.

16. McFadden KL, Hernández TD, Ito TA. Attitudes toward complementary and alternative medicine influence its use. Explore (NY). 2010;6(6):380-388. doi:10.1016/j.explore.2010.08.004

17. Vuković MH, Jakovljević MB. Structural validity and reliability of the healthcare professionals' economic reasoning questionnaire. Hospital Pharmacology - International Multidisciplinary Journal. 2015; 2(3):308-316. (www.hophonline.org)

18. Jakovljevic M, Vukovic M, Antunovic M, Dragojevic Simic V, Velickovic Radovanovic R, SiladjiMladenovic D, Jankovic N, Rankovic A, Kovacevic A, Antunovic M, Markovic V, Chia-Ching C, Tetsuji Y. Do Policy Measures Impact on Cost Consciousness of Health Care Professionals? Value in Health. 2013; 16(7):A542-A542.

19. Jakovljevic M, Vukovic M, Chen C, Antunovic 
M, Dragojevic- Simic V, Velickovic-Radovanovic R, Djendji Mladenovic S, Jankovic N, Rankovic A, Kovacevic A, Antunovic M, Milovanovic O, Markovic V, Babu NS D, Yamada T. Do Health Reforms Impact Cost Consciousness of Health Care Professionals? Results from a Nation-Wide Survey in the Balkans. Balkan Medical Journal 2016;33:8-17.

20. Wahner-Roedler DL, Vincent A, Elkin PL, Loehrer LL, Cha SS, Bauer BA. Physicians' attitudes toward complementary and alternative medicine and their knowledge of specific therapies: a survey at an academic medical center. Evid Based Complement Alternat Med. 2006; 3(4):495-501.

21. Milden SP, Stokols D. Physicians' attitudes and practices regarding complementary and alternative medicine. Behav Med. 2004; 30:73-82.
22. Jump J, Yarbrough L, Kilpatrick S, Cable T. Physicians' Attitudes Toward Complementary and Alternative Medicine. Integrative Medicine 1998; 1(4):149-153.

23. Barnes PM, Bloom B, Nahin RL. Complementary and alternative medicine use among adults and children: United States, 2007. Natl Health Stat Report. 2008; 12:1-23.

24. Shuval JT, Averbuch E. Complementary and alternative health care in Israel. Israel Journal of Health Policy Research. 2012; 1:7. https://doi. org/10.1186/2045-4015-1-7
Appendix 1. Items of the TCAM questionnaire

\section{No}

qn 1 Physical and mental health are a reflection of internal energy or vitality.

Both illness and health are reflections of the balance between positive forces, which

qn 2 makes a person feel happy and enjoys life, and negative, destructive forces within the body.

qn 3 The body is essentially self-healing, and the doctor's task is to assist in the healing process.

qn 4 Patient's symptoms should be regarded as a manifestation of the imbalance or dysfunction which affects the whole body.

qn 5 Patient's expectations, faith in the healing process and their personal values should be incorporated into the healing process.

qn 6 Traditional, complementary and alternative medicine poses a threat to human health.

qn 7 Treatment that is not scientifically recognized should not be supported.

qn 8 The effectiveness of treatment with traditional, complementary and alternative medicine methods is due to the placebo effect.

an 9 Traditional, complementary and alternative medicine includes ideas and methods that could be beneficial to conventional medicine.

qn 10 Most of the methods used in traditional, complementary and alternative medicine stimulate the natural therapeutic powers of the body.

qn 11 Traditional, complementary and alternative medicine should be subjected to further scientific research before doctors practicing conventional medicine can accept it.

qn 12 Traditional, complementary and alternative medicine should be used as a last resort when conventional medicine has nothing else to offer.

gn 13 Traditional, complementary and alternative medicine should be used in the treatment of light illnesses, not in the treatment of serious illnesses. 


\title{
Analiza stavova lekara prema metodama tradicionalne, komplementarne i alternativne medicine
}

\author{
Gordana D. Marković Petrović́ ${ }^{1}$ Gordana B. Belamarić ${ }^{2}$ \\ ${ }^{1}$ Služba za specijalističku i konsultativnu delatnost, Dom zdravlja Zemun, Beograd, Srbija \\ ${ }^{2}$ Gradski zavod za javno zdravlje Beograd, Beograd, Srbija
}

\section{KRATAK SADRŽAJ}

Uvod: Tokom poslednje dve decenije, primena metoda tradicionalne, komplementarne i alternativne medicine (TKAM) je u porastu i stiče sve veću popularnost. Najčešći razlozi za to su traganje bolesnika za novim vidovima terapije i zainteresovanost pojedinaca za promenu stila života i unapređenje zdravlja neinvazivnim, prirodnim terapijama. Uprkos prepoznavanju značaja TKAM od strane Svetske zdravstvene organizacije, veliki broj lekara još uvek nije spreman da ih prihvati kao legitiman medicinski tretman, što potencijalno predstavlja veliki javno-zdravstveni problem, jer sa sobom nosi rizik da bolesnici metode TKAM primenjuju bez znanja svog lekara. Ova činjenica ukazuje i na opasnost od odlaganja, ili izbegavanja upotrebe adekvatnog tretmana konvencionalne medicine, kao i na mogućnost interakcije između lekova konvencionalne medicine i preparata koji se koriste u TKAM.

Cilj: Cilj ovog istraživanja je ispitivanje stavova lekara o TKAM i formiranje validnog instrumenta koji bi se u tom i budućim ispitivanjima koristio.

Metodologija: Instrument korišćen za prikupljanje podataka je upitnik. Analize korišćene u statističkoj obradi dobijenih rezultata su: multipla analiza korespondencije, diskriminacione analize, Mann-Whitney testiranje, „ROC“ procedura.

Rezultati: Ispitano je 110 lekara, od kojih je 24 imalo završenu edukaciju iz neke od metoda TKAM. Multiplom analizom korespodencije prema odgovorima na pitanja, izdvojene su tri dimenzije prihvatanja TKAM. Ukupno objašnjena varijansa iznosi $98,36 \%$, a srednja vrednost Kronbahovog koeficijenta alfa za sve tri dimenzije je 0.929.

Zaključak: Edukacija lekara u oblasti tradicionalne, komplementarne i alternativne medicine igra odlučujuću ulogu u njihovom prihvatanju ovih metoda. Ona je veoma značajna i zbog toga što je sve veći broj pacijenata koji metode TKAM koriste za lečenja bez medicinskog nadzora.

Ključne reči: tradicionalna, komplementarna, alternativna medicina, lekari, stavovi 